\title{
A New Species of Pleurostachys (Cyperaceae) from Atlantic coastal Brazil
}

\author{
W. WAYT THOMAS ${ }^{1}$, MARCCUS V. ALVES ${ }^{2} \&$ RAFAEL TREVISAN ${ }^{3}$ \\ ${ }^{\prime}$ The New York Botanical Garden, Bronx, NY 10458-5126, USA. Email: wthomas@nybg.org \\ ${ }^{2}$ Departamento de Botânica, CCB, Universidade Federal de Pernambuco, Av. Moraes Rego s/n, 50940-000 Recife, PE, Brazil. \\ Email: alves.marccus@gmail.com \\ ${ }^{3}$ Departamento de Botânica, CCB, Universidade Federal de Santa Catarina, Av. R. Eng. Agrônomo Andrey Cristian Ferreira, 88040- \\ 970 Florianópolis, SC, Brazil.Email:rftrevisan@yahoo.com.br
}

\begin{abstract}
Pleurostachys arcuata is described as a new species endemic to the Atlantic forest of Brazil. It is illustrated and is compared to other species of Pleurostachys. It has the large achenes of P. macrantha but has small, axillary synflorescences similar to those of $P$. gaudichaudii.
\end{abstract}

\section{Resumo}

Pleurostachys arcuata é descrita como uma espécie nova da Mata Atlântica do Brasil. Está ilustrada e comparada com outras espécies de Pleurostachys. Tem os aquênios grandes de P. macrantha mas as sinflorescências pequenas e axilares semelhantes às de $P$. gaudichaudii.

Key words: Pleurostachys, Cyperaceae, Brazil, Atlantic forest, taxonomy

\section{Introduction}

Pleurostachys Brongn. is a small genus found exclusively in neotropical forests. Kükenthal's monograph of 1952 treated 30 species. Thomas and Alves (2008) recognized 23 species, 21 of which are endemic to Brazil's Atlantic coastal forest. Modern collections have greatly increased the number of specimens available for study, revealing several undescribed species, one of which is described here.

Most authors have maintained Pleurostachys as a separate genus closely allied to Rhynchospora Vahl (Boeckler, 1875; Clarke, 1908; Pfeiffer, 1925; Koyama, 1961; Kükenthal, 1952; Eiten, 1976; Bruhl, 1995; Goetghebeur, 1986, 1998; Soros \& Bruhl, 2000). Recent molecular studies (Thomas et al. 2009a) confirm this relationship and raise the question as to whether or not Rhynchospora is paraphyletic with respect to Pleurostachys. Because the phylogenetic relationship of Pleurostachys and Rhynchospora is still unclear, and because they are morphologically distinct, we are describing this new species as a member of the genus Pleurostachys.

Features that unite Rhynchospora and Pleurostachys in the tribe Rhynchosporeae include simple spikelets, bisexual flowers, lenticular achenes subtended by perianth bristles, and a persistent style base. Characters that distinguish Pleurostachys from Rhynchospora include an inflorescence comprising a series of axillary synflorescences, distichously (or subdistichously) arranged spikelet scales, distally plumose perianth bristles, and decurrent style bases (these are discussed at length in Thomas \& Alves, 2008). 


\section{Taxonomy}

Pleurostachys arcuata W. W. Thomas, M. Alves \& R. Trevis., spec. nov. (Fig. 1)

Pleurostachys arcuata is unique in having basal leaves which are long and wide, small synflorescences of clustered spikelets, and large achenes. It has the large achenes of P. macrantha but has the small, axillary synflorescences of P. gaudichaudii.

Type:-Brazil. Bahia: Mun. Santa Luzia, Serra da Onça, $10.8 \mathrm{~km}$ NE of Santa Luzia (30 km SW of Una) on Una-Santa Luzia road, then $4.2 \mathrm{~km} \mathrm{~N}$ on road to Serra da Onça. $39^{\circ} 30^{\prime} \mathrm{S}, 15^{\circ} 20^{\prime} \mathrm{W}$. Southern Bahian Wet Forest. Reddish clay and many rocks. Rare in forest, leaves shiny dark green, inflorescence arching to scandent. 21 Nov 1996. W. W. Thomas, A. Carvalho, A. Amorim, S. Sant'Ana \& J. L. Paixão 11367 (holotype CEPEC, isotypes K, NY).

\section{Description}

Perennial, cespitose or with short woody rhizomes. Culms arching, (30.5-) 58-212 cm long, (1-) 1.8-3 $\mathrm{mm}$ wide at lowest synflorescence, tapering to $0.8-1 \mathrm{~mm}$ below distal-most synflorescence, glabrous, triangular in cross-section. Leaves basal and cauline; basal leaves ca. 5-7 with open sheaths; sheaths gradually widening into the blade, paler than blade, plicate, $12-15 \times 1.4-1.8 \mathrm{~cm}$; blade lanceolate to linear, $15-$ $90 \times 2-2.4 \mathrm{~cm}$, dark green, usually shiny, the apex acuminate, the margins slightly antrorsely scabrous; cauline leaves (bracts) each subtending an axillary synflorescence and diminishing in size distally along the culm; sheaths closed, the basal ones 2-4 cm long. Synflorescences 4-8, each a condensed raceme of 3-6 clusters of 2-3 spikelets each, mature basal one 1.4-3.5 $\times 1.5-3 \mathrm{~cm}$, the peduncles decreasing in length at each more distal node, the basal one $6.5-8 \mathrm{~cm}$ long. Spikelets $10-20$ per synflorescence; $3.7 \times 2.9 \mathrm{~mm}$ at anthesis, lenticular, ovate in outline, pale brown; scales ca. 8 visible, distichously or subdistichously arranged, carinate, shiny, cartilaginous, the lowest 2-3 sterile, the lower ones mucronate, the intermediate ones largest, shallowly triangular, $2.8 \times 3.5 \mathrm{~mm}$. Perianth bristles persistent, 5, flattened basally, antrorsely scabrous to shortplumose, unequal, (1-) 1.5-2.4 mm long, usually one half to two thirds the length of the achene. Achenes 2.4$3.2 \times(1.7-) 2.2-2.9 \mathrm{~mm}$, deeply biconvex, broadly obovate to circular in outline, shiny, lightly wrinkled to obscurely rugulose; style base inserted in a shallow depressed area at apex of achene and decurrent along lateral margins, the depressed area transversely rhombic, $0.9-1.2 \times(1.7-) 2-2.5 \mathrm{~mm}$, the raised central portion $0.6-1.2 \times 0.8-1.0 \mathrm{~mm}$, deltate.

Distribution and ecology:-Known from the Atlantic forest region of Brazil, from the state of Bahia south to the state of Santa Catarina (Fig. 2). The known collections are from tropical submontane moist forest (Thomas \& Barbosa 2008) above $300 \mathrm{~m}$ in Bahia and Espírito Santo and below $300 \mathrm{~m}$ in Rio de Janeiro and Santa Catarina, usually among rocks. The flora of one locality, the Serra do Teimoso (Fig. 3), has been well-studied (Amorim et al. 2005) and a study of the species composition shows that the forest near the top of the mountain, where Pleurostachys arcuata was collected, is distinct from that of the lower forests (Thomas et al. 2009b).

Etymology:-The species is named for its characteristic arched culms.

Conservation Status:-Pleurostachys arcuata is restricted to intact, rocky, submontane moist forests, and is never common. Furthermore, the Atlantic forest of Brazil has been identified as one of the World's biodiversity "hotspots" (Myers et al. 2000), in part, because of continuing deforestation. Overall, the Atlantic forest has been reduced to less than 11 percent of its original extent (Ribeiro et al. 2009).

Calculating "area of occupancy" (AOO; IUCN 2012) using grid cells of $3 \times 3 \mathrm{~km}\left(9 \mathrm{~km}^{2}\right)$ following the methodology developed by Callmander et al. (2007) and Miller \& Porter Morgan (2011) results in an AOO for $P$. arcuata of $126 \mathrm{~km}^{2}$. Calculating "extent of occurrence" (EOO; IUCN 2012) results in an EOO of ca. $160,000 \mathrm{~km}^{2}$ (the $1600 \mathrm{~km}$ between the northernmost and southernmost known localities multiplied by the average width of the Atlantic forest, ca. $100 \mathrm{~km}$ ). The AOO estimate is probably too restrictive and does not take into account areas where the species probably occurs but has never been collected. The EOO estimate, on the other hand, is too broad and does not factor in range discontinuity, habitat specificity, or deforestation. We believe the most accurate reflection of its conservation status would be an IUCN Red List category of Vulnerable (VU). More collections would probably increase the AOO of P. arcuata significantly, but to less than $2000 \mathrm{~km}^{2}$. Furthermore, it occurs in a severely fragmented biome, one that continues to suffer deforestation that will diminish the number and location of its subpopulations. 


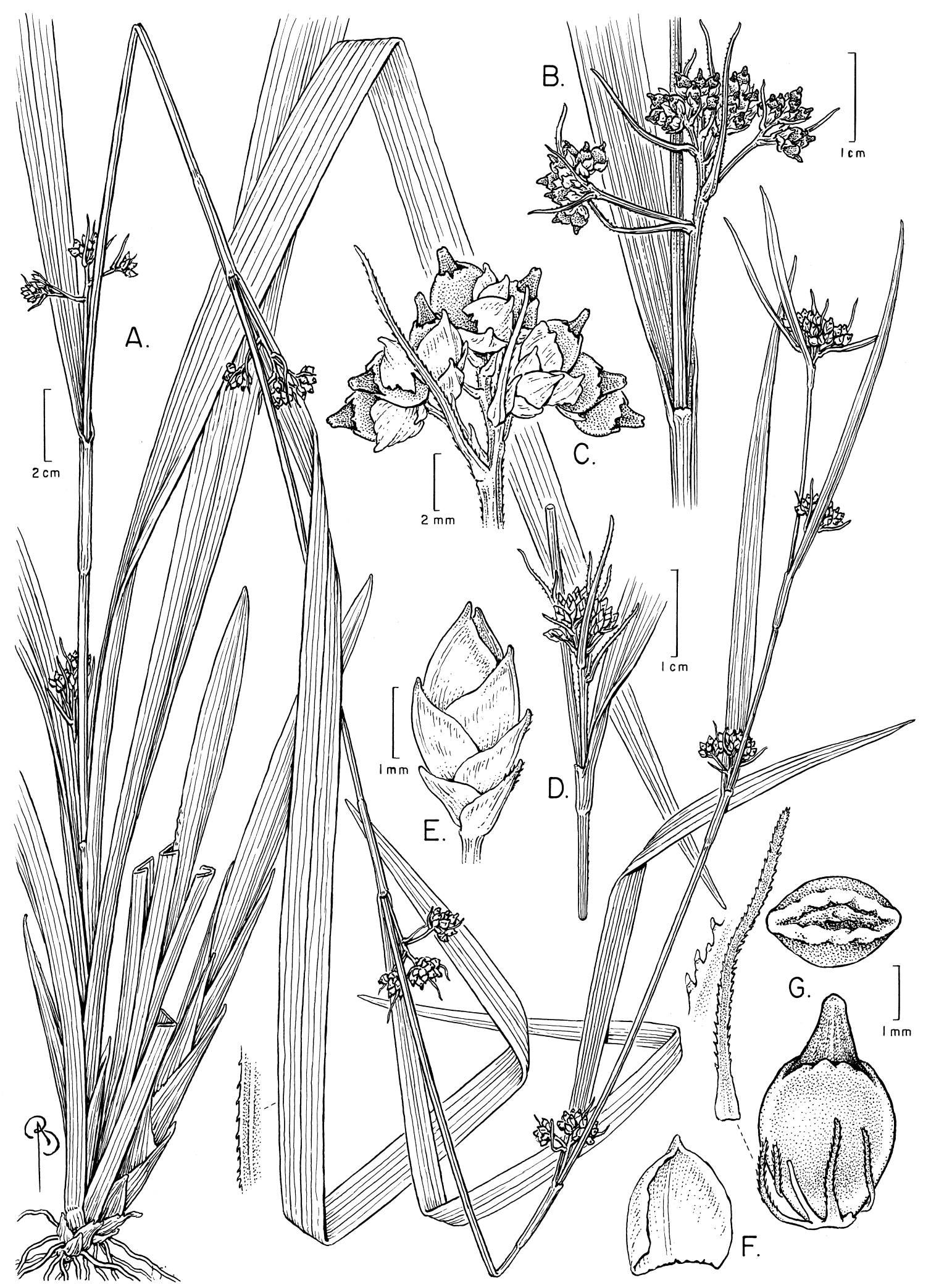

FIGURE 1. A-G. Pleurostachys arcuata. A. Plant habit. B. Synflorescence in fruit. C. Detail of one branch of synflorescence. D. Synflorescence in flower. E. Spikelet prior to anthesis. F. Spikelet scale. G. Achene, side view, top view, and detail of bristle. A-C, F, G from W. W. Thomas et al. 11367 (NY); D and E from W. W. Thomas et al. 14182 (NY). Drawn by Bobbi Angell. 
Paratypes:-BRAZIL. Bahia: Mun. Almadina, Serra Corcovado, $9.9 \mathrm{~km} \mathrm{SW}$ of Coarci on road to Almadina, then N into Fazenda São José, 1442’21"S, 39³6'12"W, 650-750 m, submontane/montane tropical moist forest with disturbed areas, herb in forest, culms arching, 19 Sep 2004, W. W. Thomas et al. 14812 (CEPEC, NY); Serra do Corcovado, accesso pela Estação da EMBASA, 1442'09"S, 39³6'14"W, 4 Nov 2011, M. M. Coelho et al. 486 (CEPEC); Serra do Sete-Paus, Rodovia de Almadina para Ibitupã,

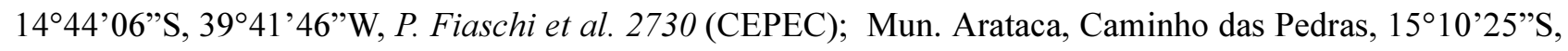
39²0’30”'W, 1000 m, 12 Oct 2005, A. M. Amorim et al. 5266 (CEPEC), 15 Jun 2006, A. M. Amorim et al. 6065 (CEPEC); Serra das Lontras, 15¹2'10"S, 39²4'29”W, 29 Apr 2006, A. M. Amorim et al. 5949 (CEPEC); Mun. Jussari, Rod. Jussari/Palmeira, 7.5 km, Fazenda Teimoso, Reserva Serra do Teimoso, 1509.37S, 39³1.74'W, 300-640 m, 15 Sep 2001, J. Jardim et al. 3922 (CEPEC, NY); 21 Aug 2003, P. Fiaschi, S. C. Sant'Ana \& J. L. Paixão 1579 (CEPEC, NY); near top of mountain, 1505'44”'S, 39³2'33"'W, W. W. Thomas et al. 13370 (CEPEC); Mun. Una [Santa Luzia], Serra da Onça, 23 Mar 2005, J. Paixão, S. Sant'Ana \& L. Carlos 378 (NY-2 dupls). Espírito Santo: Mun. Santa Teresa, Estação Biologica da Caixa D'Agua, 4 Nov 1986, W. Boone 1081 (MBML, MO); Mun. Cariacica: Reserva Biologica de Duas Bocas, 1 Jun 2000, M. Alves et al. 1945 (MBML, SP). Paraná: Mun. Guaraqueçaba, Rio de Costa. Mata pluvial encosta de morro, 50 m. 4 Feb 1971. G. Hatschbach 26270 (NY). Rio de Janeiro: Mun. Mangaratiba, RPPN Rio das Pedras, A. M. Amorim et al. 3378 (CEPEC); Mun. [probably Rio Novo], Serra do Henrique, prope Rio Novo. Sep 1894. Schwacke 10973 (RB). Santa Catarina: Mun. Blumenau, Parque Natural Municipal São Francisco de Assis, em floresta Atlântica, 265'19,82'S, 4904'44,87”W, 87 m, 18 Feb 2011, M. Verdi 5889 (FLOR, FURB).

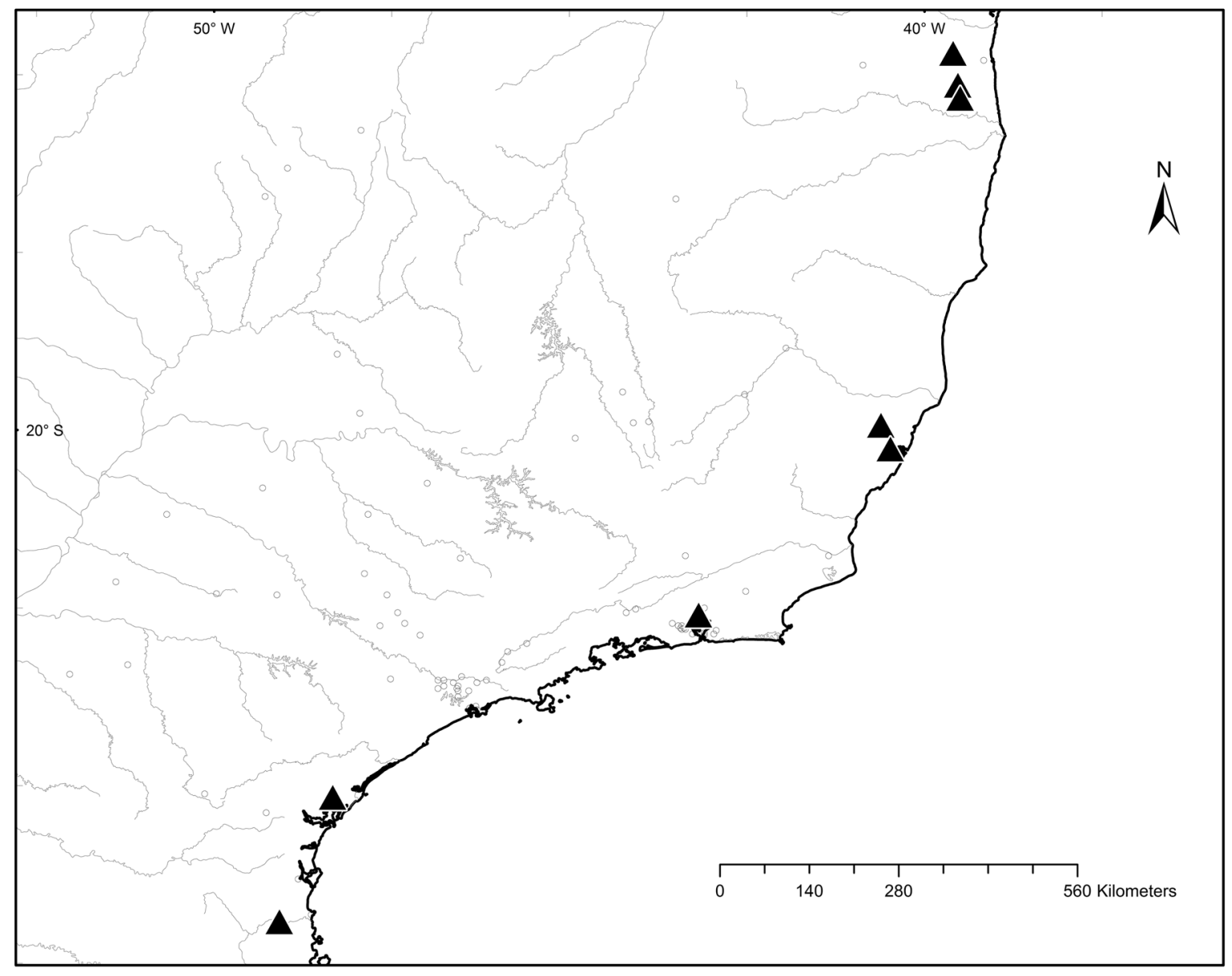

FIGURE 2. Distribution map of Pleurostachys arcuata. 
Observations:-In Kükenthal's (1952) classification, Pleurostachys arcuata would belong to section Millegranae (Thomas \& Alves 2008) because of the presence of blades on the basal leaves and the congested synflorescences. In their phylogeny of Pleurostachys based on morphological characters, however, Thomas and Alves (2008) found that section Millegranae was probably polyphyletic, and that P. arcuata (designated as "sp. nov. 1") was sister to all other species of the genus.

The only other species with achenes similar in size to those of Pleurostachys arcuata is $P$. macrantha Kunth with achenes 2.8-3.4 × 2.7-3.2 mm. Pleurostachys macrantha, however, has large, open panicles with solitary spikelets at the end of each branch. The remaining species of Pleurostachys have achenes approximately $1 \mathrm{~mm}$ long or less.

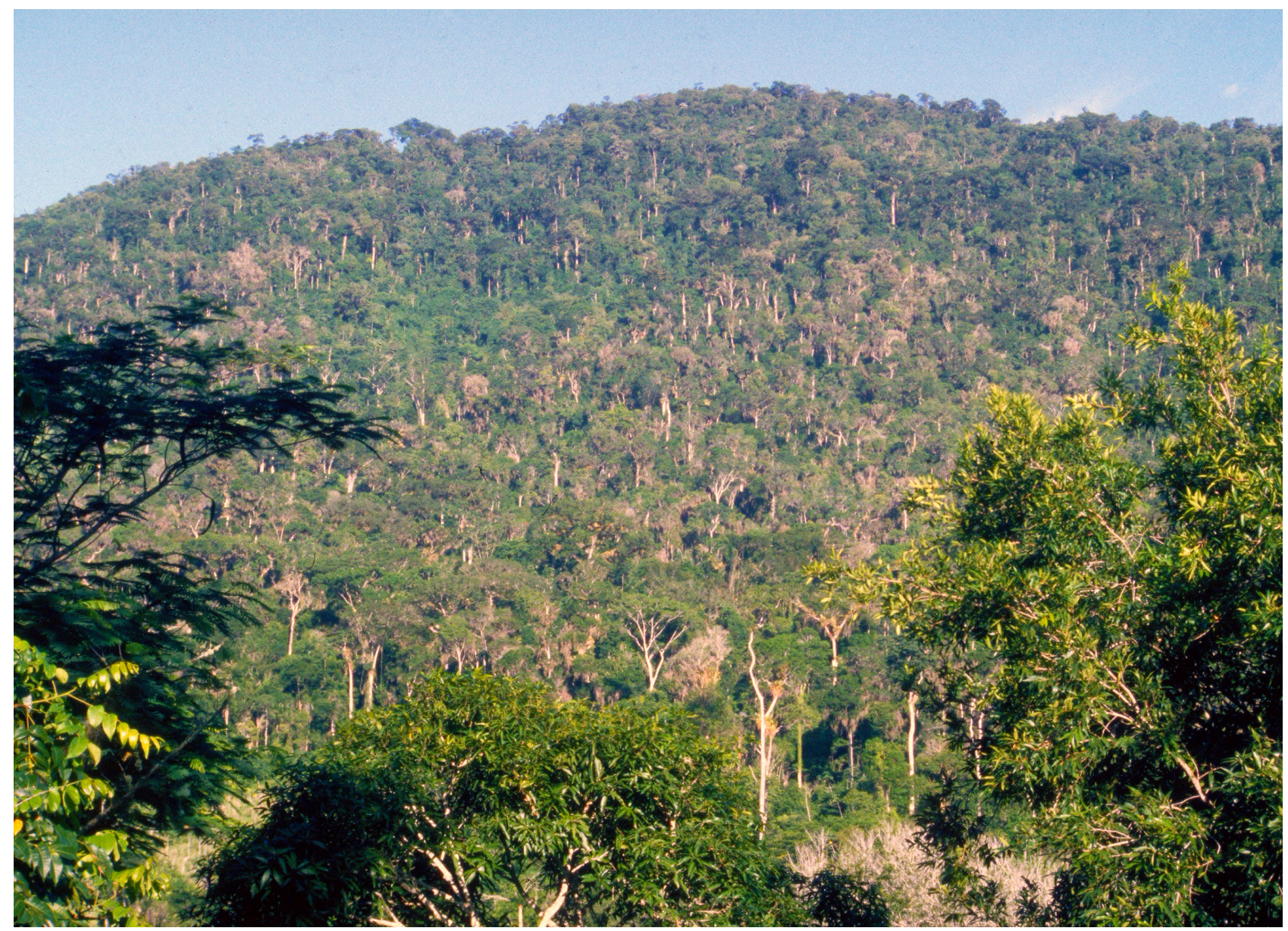

FIGURE 3. Forested slope of the Serra do Teimoso Private Reserve (RPPN), Jussari, Bahia.

\section{Acknowledgements}

Financial support for field work resulting in collections of this species was provided by the John D. and Catherine T. MacArthur Foundation, the National Science Foundation (DEB 9972116 and DEB 0516233), and the Beneficia Foundation. We thank the curators of the herbaria we consulted, especially those of CEPEC, MBM, NY, R, and RB. 


\section{References}

Amorim, A.M., Fiaschi, P., Jardim, J., Thomas, W.W., Clifton, B. \& Carvalho, A.M. (2005) The vascular plants of a forest fragment in southern Bahia, Brazil. Sida 21(3): 1727-1757.

Boeckeler, O. (1875) Die Cyperaceen des königlichen Herbariums zu Berlin. Linnaea 9: 1-152.

Bruhl, J.J. (1995) Sedge genera of the world: relationships and a new classification of the Cyperaceae. Australian Journal of Systematic Botany 8: 125-305. http://dx.doi.org/10.1071/SB9950125

Callmander, M.W., Schatz, G.E., Lowry II, P.P., Laivao, M.O., Raharimampoinona, J., Andriambololonera, S. et al. (2007) Identification of priority areas for plant conservation in Madagascar using Red List Criteria: rare and threatened Pandanaceae indicate sites in need of protection. Oryx 41: 168-176. http://dx.doi.org/10.1017/S0030605307001731

Clarke, C.B. (1908) New Genera and Species of Cyperaceae. Kew Bulletin, Add. Ser. 8: 1-196.

Eiten, L. (1976) Inflorescence units in the Cyperaceae. Annals of the Missouri Botanical Garden 63: 81-112. http://dx.doi.org/10.2307/2395224

Goetghebeur, P. (1986) Genera Cyperacearum. Een bijdrage tot de kennis van de morfologie, systematiek en fylogenese van de Cyperaceae-genera. Doctoral Thesis, Rijkuniversiteit Gent.

Goetghebeur, P. (1998) Cyperaceae. In: K. Kubitzki, H. Huber, P. Rudall, P. Stevens \& T. Stützel, Vascular flowering plants. Vol. 4. Springer, Berlin., pp. 141-189

IUCN (2012) The IUCN Red List of Threatened Species. Version 2012.2. At www.iucnredlist.org. Viewed on 13 December 2012.

Koyama, T. (1961) Classification of the family Cyperaceae 1. Journal of the Faculty of Science, University of Tokyo, sect. 3, Botany 8: 37-148.

Kükenthal, G. (1952) Vorarbeiten zu einer Monographie der Rhynchosporoideae. Pleurostachys. Botanische Jahrbücher für Systematik, Pflansengeschichte und Pflanzengeographie 75: 451-497.

Miller, J.S. \& Porter Morgan, H.A. (2011) Assessing the effectiveness of Madagascar's changing protected areas system: a case study of threatened Boraginales. Oryx 45: 201-209. http://dx.doi.org/10.1017/S0030605310000803

Myers, N., Mittermeier, R.A., Mittermeier, C.G., da Fonseca, G.A.B. \& Kent, J. (2000) Biodiversity hotspots for conservation priorities. Nature 403: 853-858. http://dx.doi.org/10.1038/35002501

Pfeiffer, H. (1925) Monographia Pleurostachydearum. I. Pars specialis descriptioque specierum. Botanisches Archhiv 9: 225-242.

Ribeiro, M.C., Metzger, J.P., Martensen, A.C., Ponzoni, F.J. \& Hirota, M.M. (2009) The Brazilian Atlantic Forest: How much is left, and how is the remaining forest distributed? Implications for Conservation. Biological Conservation 142: 1141-1153. http://dx.doi.org/10.1016/j.biocon.2009.02.021

Soros, C. \&\& Bruhl, J.J. (2000) Multiple evolutionary origins of $\mathrm{C}_{4}$ photosynthesis in the Cyperaceae. Pp. 629-636 in K. L. Wilson \& D. A. Morrison, Monocots: Systematics and Evolution. CSIRO. Melbourne.

Thomas, W.W. \& Alves, M. (2008) Towards a Revision of the Genus Pleurostachys (Cyperaceae): Preliminary Results, In: R. Naczi and B. Ford (eds.) Sedges: Uses, Diversity, and Systematics of the Cyperaceae. Monographs in Systematic Botany from the Missouri Botanical Garden 108: 269-278.

Thomas, W.W., Araújo, A.C. \& Alves, M. (2009a) (2008 online) A Preliminary Molecular Phylogeny of the Rhynchosporeae (Cyperaceae). In: W. W. Thomas, D. A. Simpson, A. A. Reznicek and J. R. Starr (eds.), Cyperaceae - Special Issue. Botanical Review 75: 22-29. http://dx.doi.org/10.1007/s12229-008-9023-7

Thomas, W.W. \& Barbosa, M.R.V. ( 2008) Natural Vegetation Types in the Brazilian Atlantic Coastal Forest North of the Rio Doce. In: W. Thomas (ed.), The Atlantic Coastal Forest of Northeastern Brazil. Memoirs of the New York Botanical Garden 100: 6-20.

Thomas, W.W., Jardim, J.G., Fiaschi, P., Mariano-Neto, M. \& Amorim, A.M. (2009b) Composição Florística e Estrutura do Componente Arbóreo de uma Área Transicional de Floresta Atlântica no Sul da Bahia, Brasil. Revista Brasileira de Botânica 32 (1): 41-54.

http://dx.doi.org/10.1590/S0100-84042009000100007 